\title{
IOs’ Role in Global Social Governance: Family Policy
}

\author{
Rianne Mahon
}

\section{INTRODUCTION}

This chapter focuses on family policy as an object of global social governance. Family policy can encompass a very wide scope, including norms governing marriage and separation, sexual and reproductive health and rights, and in-family violence. Such a broad definition would bring into focus an equally wide range of international organizations (IOs) such as the United Nations International Children's Emergency Fund (UNICEF), ${ }^{1}$ the Office of the UN High Commissioner for Human Rights (OHCHR), the United Nations Population Fund (UNFPA), the World Health Organization (WHO) and the International Organization for Migration

${ }^{1}$ If the chapter were focused on child policy per se, UNICEF would be a central actor but here it plays a more modest role, primarily as a critic of the Bretton Woods institutions' neoliberal adjustment policies in the 1980s.

Research for this chapter was funded by the Social Science and Humanities Research Council of Canada.

R. Mahon $(\bowtie)$

Department of Sociology and Anthropology, Carleton University, Ottawa, ON, Canada

(C) The Author(s) 2021

K. Martens et al. (eds.), International Organizations in Global

Social Governance, Global Dynamics of Social Policy, https://doi.org/10.1007/978-3-030-65439-9_8 
(IOM), to list just a few. In this chapter, however, I largely follow Saraceno's definition of family policy, namely: "All those public policies that are explicitly designed to affect the situation of families or individuals in their gender and intergenerational family roles, and to thus have clear, though possibly unintended, consequences for such families and individuals" $(2013,444)$. Even thus, narrowing the scope of family policies leaves open the range of objectives they may serve, such as dealing with demographic challenges (declining fertility/population aging), tackling child poverty/combating the intergenerational transmission of poverty, investing in human capital formation, encouraging women's labor force participation and promoting gender equality. The main IOs involved in this field have emphasized various aspects at different times and in different ways, reflecting divergent assumptions about the role and nature of families and their organizational mandates.

From the 1990s to 2008 , the family policy field was bifurcated, albeit traversed by a common discourse: social investment. One part, focused on family norms in the North, following the shift from the male breadwinner to the adult earner family with its work-family tensions. Here, the main IOs were the International Labour Organization (ILO) and the Organisation for Economic Co-operation and Development (OECD). The second focused on the South and policies targeting children in poor families. Although UNICEF clearly played an important role on the ground, it was the World Bank that took the lead in elaborating and disseminating the core ideas. Since the 2008 crisis, the field has come together in the Sustainable Development Goals (SDGs) that simultaneously address the Global North and South. The dominant discourse is 'inclusive growth', challenged by the more critical discourse on the 'care economy'.

Following an introduction to the analytical framework and the key IOs, the second section discusses the ILO's evolving standards for family supports and then analyzes the two parts of the field, bringing out the distinct ways in which the OECD and the World Bank interpreted social investment in the family. The third section looks at the adoption of inclusive growth by the ILO, the OECD and the World Bank in the aftermath of the 2008 financial crisis. This discursive shift, in combination with renewed attention to gender equality, involved an important 'layering' of new ideas into the organizational discourses developed in the previous period, including elements of the ILO's 'decent work' agenda and the concept of women's unpaid domestic labor. 


\section{ANALYTical Framework}

Like other chapters in this volume, this chapter combines attention to the global policy field's organizational environment with an examination of the intrinsic features of the key IOs within that field. The organizational environment is composed of the configuration of actors-here limited to IOs - in that field and the rules and belief systems that arise in the broader societal context (Niemann et al., introduction to this volume). Organizational environments structure opportunities and the range of 'legitimate' ideas even for the dominant IOs within them. At the same time, fields are subject to contestation and change. An important part of that struggle is discursive and takes place within a "universe of political discourse", which establishes the legitimate actors within the field and influences the range of acceptable policy alternatives (Jenson 1986, 25). While alternative ideas may be introduced to contest the parameters of debate, in normal times such dissident ideas tend to be confined to the margins. Openings, however, may occur in conjunctures marked by the emergence of events that give rise to more wide-ranging debates about what is to be done. At such times, diverse ideas jostle for attention. In the 1990s, the concept of social investment came to structure the way IOs interpreted policies targeting families. Since 2008, inclusive growth has risen to prominence.

In terms of the intrinsic features of the key IOs within a field, clearly the organization's mandate, membership and internal structure matter. As in previous work, however, I also find the concept of organizational discourse(s) particularly useful. Clearly, an organization's mandate and the sediment of its past practices leave their imprint on its culture, but the latter is also subject to change. The concept 'organizational discourse'- that is the "claims encapsulating long term political projects as defined by the organization in question" (Dostal 2004, 445) -is better capable of capturing these important discursive shifts. Organizational discourse thus recognizes that IOs do become involved in new projects that can significantly reshape their policy agendas and transform crucial elements of their bureaucratic cultures.

IOs often have more than one organizational discourse, however. As bureaucracies, they factor problems into manageable components. As a result, "different segments of the organization may develop different ways of making sense of the world, experience different local environments, and receive different stimuli from outside; they may also be populated by 
different mixes of profession or shaped by different historical experiences" (Barnett and Finnemore 1999, 24). Thus, a unit charged with dealing with family policy is likely to develop a distinctive way of seeing, which may (or may not) influence how other parts of the organization see the world. At the same time, the organization's dominant discourse is likely to have an impact on the way the unit engaged in family policy translates concepts circulating more broadly in its organizational environment.

The ILO can perhaps be considered the first to make family policy an object of global governance. Founded in the aftermath of World War I, its original mandate was to regulate international labor protection agreements. With the adoption of the Declaration of Philadelphia in 1944, the ILO secured a position as the main UN forum "for social questions associated with post-war reconstruction" (Hughes and Haworth 2011, 12). The ILO has a history of cooperative competition with the OECD on social policy (Leimgruber 2013), and as it became involved in development, it engaged in cooperation (and competition) with the Bretton Woods institutions in the South. Since the late 1990s, the concept 'decent work' has been central to its organizational discourse.

The two IOs that have played a key role in the elaboration of the social investment and inclusive growth discourses are the OECD and the World Bank. The OECD's mandate has been to promote growth through trade and investment liberalization, facilitate cooperation among its members and coordinate the latter's role in promoting development. Growth has remained central to its mandate but its "growth paradigm proved remarkably flexible in adapting to changing circumstances, integrating newly emerging problems and perspectives without changing its basic tenets" (Schmelzer 2016, 14). Although the Economics Department has remained guardian of the growth mandate, the Directorate for Employment, Labour and Social Affairs (DELSA) elaborated the OECD's social investment approach, which included family policy. DELSA also provides a forum for engaging with the ILO including servicing the G20 and it interacts with the European Directorate for Employment, Social Affairs and Inclusion.

The World Bank has come to see itself as 'the' knowledge organization in the field of development (Hammer 2013, 12). Its conception of development has changed over time, from an emphasis on physical infrastructure to poverty alleviation and human capital development under McNamara in the 1970s, neoliberal structural adjustment in the 1980s, and, in the 1990s, the restoration of the Bank's ability to 'see' and mitigate poverty (Vetterlein 2012). From 1996 to 2014, its Washington 
headquarters was organized into five thematic networks. The Poverty Reduction and Economic Management network contributed to the elaboration of the Bank's understanding of social investment, in which the early child development group played a key role. While the Bank thus includes diverse ways of seeing, nonetheless its Development Economics VicePresidency (DEC) has been effective in imposing a dominant perspective (Hammer 2013, 30).

The last organization is UN Women, formed in 2010 from the merger of four pre-existing agencies and units. For our purposes, the two most important of the original agencies were the United Nations Development Fund for Women (UNIFEM) and the UN International Research and Training Institute for the Advancement of Women (INSTRAW), established following the First UN Conference on Women. Headquartered in New York, UNIFEM had a network of regional offices through which it provided support to women's organizations as advocates and assisted governments in implementing their international commitments to gender equality. ${ }^{2}$ Headquartered in Santo Domingo, INSTRAW focused on gender research, training and capacity building. Prior to the formation of UN Women, both organizations had been involved in research and activities around gender and migration. Along with the ILO and the UN Research Institute for Social Development (UNRISD), UN Women is playing an important role in bringing the concept of the care economy into global discourse.

\section{Family Policy: From Social Consumption TO SOCIAL InVESTMENT}

This section covers the period from the Keynesian-welfare and developmental state forms to the rise of neoliberalism in the late 1970s. Neoliberalism has not been without its own contested failures, however. Both the ILO and UNICEF pushed back against the Washington Consensus, opening the way for the World Bank's adoption of a social investment discourse. Through the series of conferences culminating in the Fourth UN Conference on Women (Beijing) and the World Summit for Social Development in 1995, the UN remained an important site for contesting neoliberalism. In particular, the Beijing Platform of Action

\footnotetext{
${ }^{2}$ https://www.un.org/womenwatch/ianwge/gm_facts/Unifem.pdf. Accessed February 25,2020 .
} 
established the foundation for the gender equality norm while the World Summit sparked the formation of the ILO's 'decent work' discourse (Hughes and Haworth 2011, 73). Opposition to neoliberalism in the OECD came from units like DELSA and certain member states, as well as through its engagement with European intellectuals who played a central role in forging the Northern variant of the social investment discourse.

In the post-war period, the ILO acted as a global promoter of workers' social and industrial rights. In the 1950s and 1960, it adopted a series of social security conventions to protect the male breadwinner and his dependent family ${ }^{3}$ against the adverse impact of sickness, invalidity, unemployment or old age. This did not mean that it ignored working women. A series of conventions and recommendations targeting the working mother would help it to flesh out - and then to modify - its family policy. ILO Convention 003 (1919) on Maternity Protection sought to protect married and unmarried mothers from exposure to dangerous work during pregnancy. It also recommended women not work for at least six weeks following confinement, during which they should be provided with a stipend sufficient for the 'full and healthy maintenance' of herself and her child. This convention (Number 103) was revised at the 1952 meeting of the International Labour Conference to include all mothers "irrespective of age, nationality, race or creed" including those performing paid domestic work. The convention was revised again in 2000 (Number 183). Like its predecessors, Convention 183 included provision for maternity leave (now 14 weeks), employment protection, cash and medical benefits, protection from work harmful to mother or child, and established the right to paid time for breastfeeding during working hours. A key addition appeared in the accompanying Recommendation Number 191-that the employed mother or father be entitled to parental leave following the expiry of maternity leave.

In 1965, the ILO had passed Recommendation 123 that focused on the problems women face in reconciling their dual family and work responsibilities. While these problems could be addressed by measures affecting all workers (e.g. the reduction of the normal working day), the ILO also encouraged member states to facilitate the development of services, like

\footnotetext{
${ }^{3}$ A number of these conventions explicitly referred to the male breadwinner. See for example Convention Number 102 Social Security (Minimum Standards) passed in 1952. https:// www.ilo.org/dyn/normlex/en/f? p=NORMLEXPUB:12100:0::NO::P1210 _ INSTRUMENT_ID:312247. Accessed February 25, 2020.
} 
childcare and home helps. In the wake of the first two UN Conferences for Women, the ILO passed Convention 156 (Equal Opportunity and Equal Treatment of Men and Women Workers with Family Responsibilities) and its associated Recommendation 165 which build on the earlier foundations, including Article 5, reiterating working families' need for supportive services like childcare. Recommendation 165 made it clear that the growing army of precarious workers also needed such supports and included the infrastructural supports so important for easing women's burdens in the barrios and rural areas of the South, such as access to transport, clean water and energy.

Thus, the ILO's conception of the family and the kind of supports it needs evolved in response to changed material circumstances (most notably women's rising labor force participation) and the emergence of women's equality as a global norm. In addition to recognition of the adult earner family, the ILO, with its mandate centered on the world of work, was becoming aware of the need to extend these protections to the expanding informal economies of the South and of 'non-standard work' in the North. Accordingly, under Somavía's directorship, the ILO began to elaborate a new organizational discourse, centered on the concept of 'decent work'. The latter is comprised of four pillars: job creation, rights at work, social protection and social dialogue "with gender equality as a cross-cutting objective". ${ }^{4}$ Following the 2008 crisis, 'decent work' would begin to be filtered into the discourses of other IOs, as it addressed a blind spot in the latter's social investment discourse: investment in human capital would mean little if not complemented by change on the demand side (i.e. good jobs).

The OECD began to reflect on changing family forms through the efforts of its Working Party 6 (WP6) on the Role of Women in the Economy (Mahon 2015). While WP6 and its research on these issues were disbanded in 1998, DELSA took on the task of elaborating the foundations of a new organizational discourse based on an 'after-Keynesian' justification for social, including family, policies: the 'active society'. In contrast to both the Keynesian emphasis on sustaining consumption against the risks faced by the male breadwinner and the conservative discourse focused on the need to discipline an 'underclass' grown dependent on social assistance, the active society sought to enable those currently at

\footnotetext{
${ }^{4}$ https://www.ilo.org/global/topics/decent-work/lang\%2D\%2Den/index.htm. Accessed February 25, 2020.
} 
the margins, including lone mothers, to participate in the labor market and society by investing in their human capital.

Building on this foundation, New Orientations for Social Policy (1994) called for a shift from income maintenance to social policies designed to promote labor market participation. At the same time, it heralded the appearance of the adult worker family. A Caring World, prepared for the 1998 social policy ministers' meeting, focused on the adult worker family as a key support for flexible labor markets and efforts to reform social insurance systems geared to the male breadwinner family. States thus needed to facilitate work-family reconciliation via public investment in childcare and family leave policies. Seeing as such 'family-friendly' policy was a new project for DELSA, it launched a major thematic review, Babies and Bosses (2001-2007), which would lead to the institutionalization of this new organizational discourse within DELSA and the OECD. While activating lone parents and reforming continental social insurance systems remained part of this agenda, Babies and Bosses also came to emphasize support for the adult earner family through quality childcare, shared parental leave and more flexible work arrangements. While elements of the OECD's inclusive growth discourse would later be added to this conception of social investment, they can be seen more as a process of layering onto, rather than divergence from, the core assumptions.

In some respects, the World Bank's embrace of social investment could be viewed as a rediscovery, as the Bank had earlier recognized the importance of human capital development under McNamara's presidency (1968-1980). Largely forgotten following the Bank's embrace of structural adjustment programs, UNICEF's pushback against the latter in the form of 'adjustment with a human face' opened space for the survivors of the McNamara era within the Bank to again push for investment in human capital, with a focus on the poor Southern child. This child-centered version of the discourse began to be institutionalized with the creation of the post of Child Development Specialist in the then-Human Development Network. Its first occupant, Mary Eming Young, commissioned numerous studies of the issue and convened three international conferences (1996, 2000 and 2005) on Early Childhood Development (ECD). In the name of ECD, the Bank also became a leading proponent of conditional cash transfers (CCTs), which typically target mothers in poor families who are offered cash benefits in exchange for ensuring that their children get health checks and stay in school. 
Thus, the Bank's version of the social investment discourse held to the neoliberal thrust of the original Washington Consensus, while conceding a role for the 'right kind' of social policy. There the Bank took a narrower view than the OECD, focusing on very poor children to break the intergenerational cycle of poverty. Although it was prepared to offer financial support for narrowly targeted investments in young children's education, health and nutrition, local governments were expected to free up revenue for this by disinvesting social programs seen to benefit those employed in the (shrinking) formal economy. In clear contrast to the ILO and the OECD, women appeared not as workers but as human capital in the making (girls), or as mothers. Traditional maternal practices were blamed for children's malnutrition (Psacharopoulos 1995, 31), and poor families were generally faulted for failing to provide sufficient cognitive stimulation.

This apparent split within the family policy field between a genderresponsive social investment approach, focused on adult earner families in the North, and a blend of neoliberalism with traditional views of the family, focused on poor children in the South, can be somewhat misleading, however. To be sure, early childhood education and care have been incorporated into policy agendas in Latin America, framed in part by the World Bank's discourse but the ILO and UNIFEM were also active in carrying their organizational discourses to the South (Blofield and MartinezFranzoni 2015, 28). ${ }^{5}$ Thus, in Latin America and the Caribbean, the ILO has had an impact on maternity leave policies in the region (Blofield and Martinez-Franzoni, 2015). UNIFEM used its connections with national women's machineries and women's organizations to support dissemination of the UN's gender equality norm (Phillips and Cole 2009, 191). The UNFPA and the German aid agency brought together Latin American feminist scholars to produce an important volume on the tension between changing family norms and policy practices (Mora et al. 2006) while the UN Economic Commission for Latin America and the Caribbean (ECLAC) has disseminated ideas more in tune with the OECD's discourse than the World Bank's (Mahon 2018).

\footnotetext{
${ }^{5}$ They do not identify the Bank as the key IO here but their description of the dominant frame-early development of the human capital of poor children-is more consistent with the Bank's discourse than that of the OECD or the ILO.
} 


\section{Inclusive Growth and THe CARe ECONOMY: Implications for Family Policy Discourses}

The 2007 food crisis and the 2008 financial crisis opened a new contested failure of neoliberal orthodoxies. While absolute poverty (in the South) remained of concern, a series of studies by the leading IOs-World Bank (2006), ILO (2008) and OECD (2008, 2011)-lent credence to the arguments of critical social movements that the top one percent were capturing the lion's share of growth dividends. The (re)discovery of inequality, in turn, helped to get other IOs to incorporate the ILO's 'decent work' agenda and created room for dissemination of the idea of inclusive growth. At the same time, while feminists brought the concept of women's unpaid domestic labor to the fore, the Stiglitz, Fitoussi and Sen (2009) report gave it added prominence by calling for a broadening of income measures to include unpaid care work. The OECD and the World Bank reports on gender equality (2012) also acknowledged women's unpaid domestic labor. These developments paved the way for the global adoption of the three Rs-recognize, reward and redistribute unpaid domestic labor - which would subsequently be brought together with the idea of decent work in the broader concept of the care economy. All of these discursive developments held implications for thinking about family policy.

These institutional and discursive changes in the environment are reflected in the IOs' organizational discourses. All three IOs have embraced inclusive growth, along with elements of the ILO's decent work discourse. All three have come to recognize the importance of women's unequal share of unpaid domestic work. At the same time, each translates these into terms that modify its pre-existing organizational discourse.

The crisis provided an opening for the ILO to get other IOs to recognize that informality and precarious work were making it more difficult for families to earn sufficient incomes. Prior to the crisis, the ILO had also begun to elaborate an additional strategy - a global social protection floor ${ }^{6}$ - to address this. More specifically, the floor meant national commitments to address important family needs: essential health care, including maternity care, that meets the criteria of availability, accessibility, acceptability and quality; basic income security for all children, including

\footnotetext{
${ }^{6}$ For a detailed analysis of the development and dissemination of this idea, see Deacon (2013).
} 
access to nutrition, education, care and any other necessary goods and services; income security for active age adults unable to earn adequate incomes due to maternity, illness, unemployment or disability; and basic income security for older persons. If implemented, the floors would help families currently excluded from social insurance schemes by informality or precarity to provide for their needs across the life cycle.

Elsewhere I have described the broader changes to the OECD's dominant organizational discourse (Mahon 2019). A key change was the adoption of the New Approaches to Economic Challenges (NAEC), which posed a direct challenge to the orthodox ideas of the hitherto dominant Economic Department. NAEC's inclusive growth can be seen as enhancing the centrality of DELSA's organizational discourse within the OECD as a whole, as social investment remains central to the NAEC's conception: "a reorientation away from a risk-only approach to welfare provision, towards a life-long enabling platform that furnishes individuals with capacity enhancing assets in the form of human and social capital, good health and active support in labour markets...that builds on strong foundations for learning and adaptation for life and through life" (OECD 2017a, 5).

This does not mean that the OECD failed to incorporate new ideas into its organizational discourse. Inequality has received considerable attention since the publication of Growing Unequal, and this concern has been institutionalized through the creation of the OECD's Centre for Equality and Opportunity. At the same time, the latter's work reflects the OECD's continued commitment to the adult earner family. For instance, Under Pressure: The Squeezed Middle Class (2018a) reiterates the lessons learned through Babies and Bosses. It calls for measures to promote women's fulltime employment, noting that in contrast to dual-income families, one and a half earner families make up a growing share of lower-middle-income families.

The OECD's conception of the gender-equal family now includes recognition of women's unpaid labor. The OECD has also taken on elements of the ILO's decent work agenda, most notably through its renewed Jobs Strategy, Good Jobs for All in a Changing World of Work (2018b). This shift is also reflected in its ongoing studies of child policy (OECD 2015, 2016). While continuing to stress encouraging parental employment (preferably full-time) through the provision of appropriate supports (paid leave, quality childcare), measures to support "the creation of stable, high quality jobs that are both sufficient and accessible to the lower-skilled parents" have been added onto this (Thévenon and Manfredi 2018, 11). In other 
words, it is not sufficient to enable adult family members to work; they also need to be able to find and secure good jobs.

While the family discourse that built on the Babies and Bosses foundation focused on families with children, the OECD has come to recognize that eldercare is also an important issue that families, especially women, have to deal with. Here again, socio-economic and gender inequality are of concern. Thus, the background documents prepared for its high-level conference on policies for equal aging noted that countries with higher levels of social protection for long-term care had lower rates of informal care and thus less gender inequality $(2018 \mathrm{c})$. The main message, however, remained the importance of supporting the adult earner family: "While many countries need to improve long-term care supports and continue pension reforms to make retirement income systems financially and socially sustainable, policy efforts to limit old-age inequalities cannot rely only on measures targeted to older people. It is more efficient to address socioeconomic inequalities when they arise rather than remedy their consequences, including gender inequalities, which tend to widen with old age" (OECD 2018c, 6). ${ }^{7}$

The changing environment was also reflected in the Bank's discourse and the Bank, in turn, contributed to those changes. The Growth Commission (2006-2008) played a role both in the adoption-and the wider dissemination - of inclusive growth. The Commission's report differed, however, in important ways from the way the Bank came to translate inclusive growth. For instance, while the adoption of inclusive growth meant for the Bank the addition of 'shared prosperity' defined as improving the incomes of the bottom 40 percent, the Commission had also proposed dealing with those at the top by sharing the wealth through the tax system (Commission 2008, 62). Although both versions emphasized investment in human capital, the Commission noted that such investment would not bear fruit without complementary development of the demand for quality labor (Commission 2008, 37).

More specifically, the Bank's conception of inclusive growth continued the earlier focus on investment in human capital, with a particular emphasis on the early years. One whole chapter of The Changing Nature of Work focuses on lifelong learning, in which early child development is assigned a foundational role: "The most effective way to acquire the skills demanded by the changing nature of work is to start early. Early investment in

\footnotetext{
${ }^{7}$ See also Preventing Ageing Unequally (2017).
} 
nutrition, health, social protection, and education lay strong foundations for the future acquisition of cognitive and socio-behavioral skills. They also make future skills acquisition more resilient to uncertainty. Early childhood investments are an important way to improve equality of opportunity" (World Bank 2019, 73). Early child development programs continue to be given pride of place in the report's 'new social contract'.

Like the OECD, the Bank has had to deal with the issue of demand for labor. Its 2013 World Development Report, Jobs, discussed the ILO's concept of "decent work" (World Bank 2013, 15-17). However, while it agreed that those in the informal sector needed a voice, it did not see collective bargaining as the way to achieve this and cautioned against too stringent labor market regulations. Its later report, The World of Work, however, nods in the direction of the ILO's social protection floor where it appears under the rubric of 'progressive universalism' $(2019,106)$. Progressive universalism would involve extending coverage to all in the form of a basic level of social assistance, to be complemented by basic social insurance covering 'contingencies' like maternity. A somewhat more generous social insurance system would be mandated for formal sector workers, supplemented by a 'nudged' or third-tier voluntary system.

Women also feature as more than just mothers and girls in the Bank's inclusive growth discourse. The Bank's 2012 World Development Report, Gender Equality and Development, portrayed investment in gender equality as 'smart economics'. The Bank's 2016-2023 Gender strategy, Gender Equality, Poverty Reduction and Inclusive Growth, reiterated the 2012 report's arguments for investing in women and girls as smart development policy: “increased women's labor force participation and earnings are associated with reducing poverty and faster growth; income, employment and assets empower women, which benefits men, children and society as a whole" (World Bank 2016, 12). Now programs like center-based childcare are presented as a 'double win', helping increase girls and women's engagement in education and productive activities while promoting early development and lifelong learning for young children (World Bank 2016, 38). Women's unequal share of unpaid domestic work is also recognized and warrants redistribution by including men and boys and through the provision of care services, including eldercare. The 2019 World Development Report recognizes that women's informal caregiving interferes with their engagement in the labor market and goes on to note that "Effective social care entails reimagining a role for the state in reducing involuntary unemployment by providing services in several areas. These 
include childcare, disability and old-age care, psychological support for the long-term unemployed, support for social kitchens, and rehabilitation..." (World Bank 2019, 126).

This raises the broader question of the 'care economy', a concept which the ILO and UN Women have helped to put on the agenda. As Ilkkaracan notes, the care economy "entails the production and consumption of goods and services necessary for the physical, social, mental and emotional well-being of care-dependent groups, such as children, the elderly, the ill and people with disabilities, as well as healthy, prime working age adults" $(2018,8)$. UNRISD's pioneering study, the Political and Social Economy of Care (2006-09), can be credited for going beyond the 'care crisis' in the North to show that care is also an issue for the South. Much of that care continues to be carried out in the home as unpaid labor by family members or the low-paid labor of domestic workers. Its conclusions presaged the 3Rs, arguing for (1) recognition and guaranteed rights of caregivers and receivers; (2) distribution of the costs more evenly across society; (3) the support of professional, decently paid and compassionate forms of care (UNRISD 2016). Investing in the development of quality care services provided by workers who receive fair wages can offer both direct supports to families and generate a substantial number of new 'decent' jobs if, as the ILO argues, the high road to the care economy is taken. To this the ILO would add voice (or representation) for care workers, care recipients and unpaid caregivers (ILO 2018, xliii). Moreover, as the ILO report, Care Work and Care Jobs for the Future of Decent Work, notes, such jobs are not likely to be replaced by robots given the relational nature of care work (ILO 2018, xxvii). In other words, the care economy holds the potential for generating decent work while providing families with the supports they need.

In the WDR 2019 report, the Bank seems to recognize this potential, but in other documents, it is clearly looking to the market to create these jobs. Thus, its gender strategy notes, "Governments can establish supportive business practices to foster the development of care services and intervene to encourage greater involvement of fathers in childcare and men in care for sick and elderly dependents. The private sector can invest in care services for better business outcomes and promote approaches that help workers of both sexes balance their work and family responsibilities" $(2016,44)$. Through the International Finance Corporation, the Bank has developed the 'business case' for such employer-supported childcare (IFC 2017). 
The very labor-intensive character of much of care work, however, means that it is difficult to combine private, for-profit provision with decent work and decent care. The 'gold standard' is most closely approximated in the Nordic countries, where such services are typically both publicly financed and publicly provided (Esping-Andersen 1999). To be sure, not all states currently possess the capacity to provide quality care with decent working conditions nor are they likely to do so in the near future. Nevertheless "if NGOs, social enterprises or businesses are to act as the primary institutional framework for social provisioning, the infrastructure still needs to be financed by the state" (Ilkkaracan 2018, 38). To this might be added the need for "fiscal space which would mean abandoning austerity-oriented macro-economic policies and investing in human capabilities while relieving women of unpaid work in the family and generating (decent) employment" (UN Women 2019, chapter 5).

\section{Conclusions}

This chapter has traced shifts in global social policy discourses directed at families, from the ILO's post-war conventions that supported the development of social security for the male breadwinner family through to the current family as it appears in the inclusive growth and care economy discourses. The original split in the global family policy environment reflected the post-war division between the North and the South. The crises of the Keynesian-welfare and developmental state forms opened the way for neoliberalism. Although neoliberalism may have become dominant, it was challenged and subject to change. The OECD developed a concept of social policy focused on investing in the adult earner family. In response to UNICEF's arguments and inspired by US research on policies to help poor families, the World Bank, in turn, rediscovered poverty and investment in human capital, especially that of the child, as a solution in the 1990s.

The ILO and UNRISD began to challenge these two variants of social investment as the new millennium dawned. The ILO's concept of decent work highlighted an important lacuna: investment in developing human capital requires an environment favorable to the creation of good jobs, yet labor and commodity market deregulation were generating the opposite. The ILO's idea of a global social protection floor addressed another aspect of the same phenomenon-the growth of non-standard and informal economy jobs excluded a growing number of families from traditional 
social protections. In the meantime, feminists were pushing for the recognition of women's unpaid domestic labor. At the same time, research within the key IOs was beginning to document the growth of inequality within as well as between countries. The food crisis of 2007 and the financial crisis of 2008 opened the way for these ideas to be incorporated in the discourses of the OECD and the World Bank and to do so in ways that blurred the old North-South division. The seeds of a conception of a care economy, an idea that calls for a more radical rethinking of how to support families, were planted by UNRISD and the ILO and UN Women have become its champions

There are a few important issues that this chapter has not been able to deal with. First, while the nuclear, adult earner family may be the new norm, it is by no means the only form. In some parts of the world, the extended family remains important (UN Women 2019, chapter 2). This is important to bear in mind, especially given the increase in transnational families and the transnational care chains to which these have given rise, as mothers and/or fathers migrate to secure family livelihoods, leaving children in the care of others, often other family members. IOs like the OECD, the World Bank and the International Organization for Migration (IOM) have grasped aspects of these care chains, albeit in a fragmented manner (Mahon, 2020). With its focus on decent work and the care economy, the ILO has done better and UN Women's (2019) most recent report devotes a whole chapter to families on the move. The chapter has also neglected the heteronormative assumptions that often lie at the heart of global family policy discourses. In this context, it is worth noting the 2018 OECD Ministerial Policy Statement, Social Policy for Shared Prosperity, which recognized "the continued challenges faced by historically disadvantaged groups in our countries, including racial and ethnic minorities; indigenous communities; migrants, refugees, and other displaced persons; lesbian, gay, bisexual, transgender, and intersex (LGBTI) people; older persons; and people with disabilities" (OECD 2018d, 3 ).

A second set of issues has to deal with the resources needed to realize the promises of 'inclusive growth' and the care economy. Clearly, this involves challenging the austerity policies adopted by many countries, often with the support of the IMF and the World Bank. It would also involve dealing with the issue of tax avoidance, especially by large corporations like Amazon and Google as well as the very wealthy. In this respect, the OECD/G20 Multilateral Convention to Implement Tax Treaty Related Measures to Prevent Base Erosion and Profit Sharing (BEPS), 
which has garnered official support from over 125 countries, is potentially important. $^{8}$

\section{REFERENCES}

Barnett, Michael N., and Martha Finnemore. 1999. "The Politics, Power and Pathologies of International Organizations." International Organization 53 (4): 699-732.

Blofield, Merike, and Juliana Martinez-Franzoni. 2015. Are Governments Catching Up? Wor-Family Policy and Inequality in Latin America Produced for the Progress of the World's Women 2015-16. New York: UN Women.

Commission on Growth and Development. 2008. "The Growth Report: Strategy for Sustainable Growth and Inclusive Development.” Washington DC: IBRD/ World Bank Group.

Deacon, Bob. 2013. Global Social Policy in the Making: The foundations of the social protection floor. Bristol: Policy Press.

Dostal, Jörg Michael. 2004. "Campaigning on Expertise: How the OECD framed EU Welfare and Labour Market Policies - and why Success could trigger Failure." Journal of European Public Policy 11 (3): 440-460.

Esping-Andersen, Gøsta. 1999. Social Foundations of Postindustrial Economies. Oxford: Oxford University Press.

Hammer, Peter J. 2013. Change and Continuity at the World Bank: Reforming Paradoxes of Economic Development. Cheltenham: Edward Elgar.

Hughes, Steve, and Nigel Haworth. 2011. The International Labour Organistion (ILO): Coming in from the cold. London and New York: Routledge

Ilkkaracan, Ipek. 2018. "Promoting Women's Economic Empowerment: Recognizing and Investing in the Care Economy.” May Discussion Report for UN Women. New York: UN.

ILO. 2008. World of Work Report 2008: Income Inequalities in the Age of Financial Globalization. Geneva: ILO.

ILO. 2012. Gender Equality and Decent Work: Selected ILO Conventions and Recommendations that promote gender equality as of 2012. Geneva: ILO.

ILO. 2016. Women at Work Trends 2016. Geneva: ILO.

ILO. 2018. Care work and care jobs for the future of decent work. Geneva: ILO.

International Financial Corporation/World Bank Group. 2017. Tackling Child Care: The Business Case for Employer Supported Child Care. Washington: International Financial Corporation/World Bank Group.

Jenson, Jane. 1986. "Gender and Reproduction or Babies and the State". Studies in Political Economy 20 (9): 9-46.

\footnotetext{
${ }^{8}$ http://www.oecd.org/tax/treaties/multilateral-convention-to-implement-tax-treatyrelated-measures-to-prevent-beps.htm. Accessed February 25, 2020.
} 
Leimgruber, Matthieu. 2013. "The Embattled Standard-bearer of Social Insurance and Its Challenger: The ILO, The OECD and the 'Crisis of the Welfare State', 1975-1985." In Globalizing Social Rights, edited by Sandrine Kott and Joëlle Droux, 293-309. Basingstoke: Palgrave Macmillan.

Mahon, Rianne. 2015. "Articulating a Feminist Agenda Within the OECD: The Working Party on the Role of Women in the Economy". Social Politics 22 (4): 585-610.

Mahon, Rianne. 2018. "Shaping the Way IOs 'See' Gender Equality: the OECD and ECLAC." In Handbook on Gender and Social Policy, edited by Sheila Shaver. Edward Elgar Publishing.

Mahon, Rianne. 2019. "Broadening the social investment agenda: The OECD, the World Bank and Inclusive Growth." Global Social Policy 19 (1-2): 121-138.

Mahon, Rianne. 2020. "Transnational Care Chains as seen by the OCED, the World Bank and the IOM." In Shaping Policy Agendas: The Micro-Politics of Economic International Organizations, edited by David Dolowitz, Magdaléna Hadjiisky and Romuald Normand, 77-94. Edward Elgar Publishing.

Mora, Luis, María José Moreno Ruiz, and Tania Tohner. Eds. 2006. Cobesión social, politicas conciliatorieas y presupuesto público: una mirada desde elgenera. UNFPA-GTZ

OECD, IMF, and World Bank Group. 2014. Achieving Stronger Growth by Promoting a More Gender-Balanced Economy Prepared for the G20 Labour and Employment Ministerial Meeting. Melbourne, Australia 10-22 September. Melbourne: OECD, IMF and World Bank Group.

OECD. 1994. New Orientations for Social Policy Social Policy Studies. Volume 1. Paris: OECD.

OECD. 1999. A Caring World: The New Social Policy Agenda. Paris: OECD.

OECD. 2002. Babies and Bosses: Reconciling Work and Family Life. Volume 1: Australia, Denmark and the Netherlands. OECD.

OECD. 2003. Babies and Bosses: Reconciling Work and Family Life. Volume 2: Austria, Ireland and Japan. Paris: OECD.

OECD. 2004. Babies and Bosses: Reconciling Work and Family Life. Volume 3: New Zealand, Portugal and Switzerland. Paris: OECD.

OECD. 2005. Babies and Bosses: Reconciling Work and Family Life Volume 4: Canada, Finland, Sweden and the United Kingdom. Paris: OECD.

OECD. 2006. Starting Strong II: Early Childhood Education and Care. Paris: OECD.

OECD. 2007. Babies and Bosses: Reconciling Work and Family Life: A Synthesis of Findings for OECD Countries. Paris: OECD.

OECD. 2008. Growing Unequal: Income Distribution and Poverty in OECD Countries. Paris: OECD.

OECD. 2011. Divided We Stand: Why Inequality Keeps Rising. Paris: OECD.

OECD. 2012. Closing the Gender Gap: Act Now. Paris: OECD. 
OECD. 2013. Closing the Gender Gap: Act Now. Paris: OECD.

OECD. 2015. How's Life For Children? Paris: OECD.

OECD. 2016. Enhancing Child Well-Being to Promote Inclusive Growth prepared for the meeting of Council at the Ministerial Level. June 1-2, 2016 http:/ / www. oecd.org/officialdocuments / publicdisplaydocumentpdf/?cote=DELSA/ ELSA(2016)7/REV1\&doclanguage=en. Accessed April 5, 2018.

OECD. 2017a. Bridging the Gap: Inclusive Growth 2017 Update Report OECD Publishing. Paris: OECD.

OECD. 2017b New Approaches to Economic Challenges: Towards a New Narrative Consultation Draft July, 7.2017 Paris: OECD

OECD. 2018a. Under Pressure: The Squeezed Middle Class. Paris: OECD.

OECD. 2018b. Good Jobs for All in a Changing World of Work: The OECD Jobs Strategy. Paris: OECD.

OECD. 2018c. Older and Wiser: Population Ageing. Issue Briefs for the 2018 Ministerial Meeting on Social Policy, Canada May 15, 2018.

OECD 2018d. Social Policy for Shared Prosperity: Embracing the Future Ministerial Policy Statement https://www.oecd.org/social/ministerial/ministerialstatement-2018.pdf. Accessed January 31, 2020

Phillips, Lynne, and Sally Cole. 2009. "Feminist Flows, Feminist Fault Lines: Women's Machineries and Women's Movements in Latin America." Signs 35 (1): 185-211.

Psacharopoulos, George. 1995. Building human capital for better lives (English). Directions in development. Washington, D.C.: The World Bank. http://documents.worldbank.org/curated/en/617741468765916089/Building-humancapital-for-better-lives. Accessed September 11, 2019.

Saraceno, Ciara. 2013. "Family Policies" in The Routledge Handbook of the Welfare State, edited by Bent Greve. 381-390. London: Routledge

Schmelzer, Matthias. 2016. The Hegemony of Growth: The OECD and the Making of the Economic Growth Paradigm. Cambridge: Cambridge University Press.

Stiglitz, Joseph, Amartya Sen, and Jean Paul Fitoussi. 2009. Report by the Commission on the Measurement of Economic Performance and Social Progress.

The World Bank. 2005. World Development Report 2006: Equity and Development. Washington DC: The World Bank.

The World Bank. 2011. World Development Report 2012: Gender Equality and Development. Washington DC: The World Bank.

The World Bank. 2012. World Development Report 2013: Jobs. Washington DC: The World Bank.

The World Bank. 2016. Gender, Poverty Reduction and Inclusive Growth. 2016-2023 Gender Strategy. Washington DC: The World Bank.

The World Bank. 2019. World Development Report: The Changing Nature of Work. Washington DC: The World Bank. 
Thévenon, Olivier, and Thomas Manfredi. 2018. "Child Poverty in the OECD: Trends, determinants and policies to tackle it." OECD Social, Employment and Migration Working Papers 218 DELSA/ELSA/WE/SEM (2018)17 18.10.2018. Paris: OECD.

UN Women. 2018. Turning Promises into Action: Gender Equality in the 2030 Agenda for Sustainable Development. New York: UN Women.

UN. 2019. Progress of the World's Women 2019: Families in a Changing World. New York: UN.

UNRISD. 2016. Policy Innovation for Transformative Change: Implementing the 2030 Agenda. Geneva: UNRISD. http://www.unrisd.org/unrisd/website/ projects.nsf/(httpProjects)/68C859D4A2AD6C5DC1257F7A0034FC56?O penDocument. Accessed February 25, 2020.

Vetterlein, Antje. 2012. "Seeing like the World Bank on Poverty" New Political Economy 17 (2): 35-58.

World Bank. 2013. World Development Report 2013: Jobs. Washington DC: World Bank.

Open Access This chapter is licensed under the terms of the Creative Commons Attribution 4.0 International License (http://creativecommons.org/licenses/ by $/ 4.0 /$ ), which permits use, sharing, adaptation, distribution and reproduction in any medium or format, as long as you give appropriate credit to the original author(s) and the source, provide a link to the Creative Commons licence and indicate if changes were made.

The images or other third party material in this chapter are included in the chapter's Creative Commons licence, unless indicated otherwise in a credit line to the material. If material is not included in the chapter's Creative Commons licence and your intended use is not permitted by statutory regulation or exceeds the permitted use, you will need to obtain permission directly from the copyright holder.

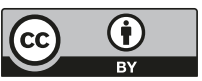

